\title{
Multispecialty consensus on diagnosis and treatment of headache
}

\author{
Stephen D. Silberstein, MD; and Jay Rosenberg, MD
}

Patients experience headache more than any other type of pain. Headache accounts for over 10 million physician visits annually. ${ }^{1,2}$ Relatively few headache sufferers receive appropriate diagnosis and adequate care. Migraine sufferers are often the most dissatisfied patients; half of those who consult stop seeking medical care for their headaches. Only $28 \%$ of sufferers are very satisfied with their usual treatment. ${ }^{3,4}$ Migraine has major implications for the patient's job and for his or her family and social life.,4 Migraine sufferers experience significant disability, lost work days, and diminished quality of life, accounting for over $\$ 13$ billion a year because of missed work days. ${ }^{4}$

An estimated $18 \%$ of women and $6 \%$ of men have migraines; about half never receive a medical diagnosis. ${ }^{6}$ There have been a number of advances in the diagnosis and treatment of migraine and great strides in understanding its pathogenesis. In the service of education and patient care, the American Academy of Neurology (AAN) has led the multidisciplinary US Headache Consortium to develop an evidence-based practice parameter on migraine. Seven organizations participated in the Consortium: the American Academy of Family Physicians, the AAN, the American Headache Society, the American College of Emergency Physicians, the American College of Physicians, the American Osteopathic Association, and the National Headache Foundation. This unique collaborative organization worked to develop a unified approach to treating migraine. Physicians from all seven groups actively participated in the project to ensure that all aspects of migraine diagnosis, treatment, and prevention were considered.

The practice parameter contains five parts: Overview of Program Description and Methodology; Neuroimaging in Patients with Nonacute Headache; Pharmacological Management of Acute Attacks; Behavioral and Physical Treatments; and Pharmacological Management for Prevention of Migraine. The goals of the practice parameter are to reduce attacks, improve the response to medication, and restore pa- tients' ability to function. The sections describe strategies for: 1) preventing migraine; 2) understanding its causes; 3 ) involving the patient in the treatment plan; 4) following progress; and 5) measuring success. The practice parameters also help physicians select patients who are likely to benefit from the prevention and treatment strategies by providing information about organized pharmacologic and nonpharmacologic approaches.

The evidence-based practice parameter for the migraine patient will be widely disseminated and can provide a basis for future outcomes research. This effort, one of the first, and certainly the most extensive, cooperative projects to develop practice parameters across disciplines, reflects the concern for the migraine patient of the physician-members of the organizations, as evidenced by their willingness to collaborate on this rigorous project. The guidelines are intended to improve care and outcomes for all migraine sufferers.

The practice parameter for migraine is now available on the Neurology web site (http://www.aan.com) and by request through AAN Customer Service (800879-1960). A short version of the practice parameter is being prepared for publication in Neurology.

\section{References}

1. Lipton RB, Stewart WF, von Korf M. Burden of migraine: societal costs and therapeutic opportunities. Neurology 1997; 48(suppl 3):S4-S9.

2. National Center for Health Statistics. Vital and health statistics of the United States. DHEW, PHS Publication No. 53. Advance data. Hyattsville, MD: National Center for Health Statistics, 1979.

3. Lipton RB, Stewart WF, Simon D. Medical consultation for migraine: results from the American migraine Study. Headache 1998;38:7-96.

4. Hu HX, Markson LE, Lipton RB, Stewart WF, Berger MC. Burden of migraine in the United States. Arch Intern Med 1999;159:813-818.

5. Von Korf M, Stewart WF, Simon D, Lipton RB. Migraine and reduced work performance. Neurology 1998;50:1741-1745.

6. Stewart WF, Lipton RB, Celentano DD, Reed ML. Prevalence of migraine in the United States. JAMA 1992;267:64-69. 


\section{Neurology}

\section{Multispecialty consensus on diagnosis and treatment of headache \\ Stephen D. Silberstein and Jay Rosenberg \\ Neurology 2000;54;1553 \\ DOI 10.1212/WNL.54.8.1553}

\section{This information is current as of April 25, 2000}

\section{Updated Information \&} Services

References

Citations

Permissions \& Licensing

Reprints including high resolution figures, can be found at: http://n.neurology.org/content/54/8/1553.full

This article cites 5 articles, 1 of which you can access for free at: http://n.neurology.org/content/54/8/1553.full\#ref-list-1

This article has been cited by 9 HighWire-hosted articles: http://n.neurology.org/content/54/8/1553.full\#\#otherarticles

Information about reproducing this article in parts (figures,tables) or in its entirety can be found online at:

http://www.neurology.org/about/about_the_journal\#permissions

Information about ordering reprints can be found online:

http://n.neurology.org/subscribers/advertise

Neurology ${ }^{\circledR}$ is the official journal of the American Academy of Neurology. Published continuously since 1951, it is now a weekly with 48 issues per year. Copyright . All rights reserved. Print ISSN: 0028-3878. Online ISSN: 1526-632X.

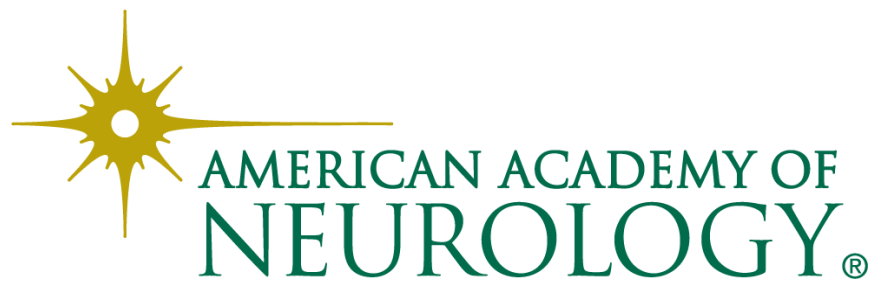

